\title{
Recombinant Fractalkine
}

National Cancer Institute

\section{Source}

National Cancer Institute. Recombinant Fractalkine. NCI Thesaurus. Code C2257.

A pro-inflammatory delta chemokine with potential antineoplastic activity. Fractalkine induces the adhesion and migration of T lymphocytes, monocytes and natural killer (NK) cells. In lymphomas, this agent may promote cell-mediated lympholysis by recruiting activated NK cells. ( $\mathrm{NClO4})$ 